\section{Survey of Hazelnut Cultivars for Response to Eastern Filbert Blight Inoculation}

\author{
China F. Lunde', Shawn A. Mehlenbacher ${ }^{2}$, and David C. Smith \\ Department of Horticulture, Oregon State University, 4017 Agricultural and \\ Life Sciences Building, Corvallis, OR 97331
}

Additional index words. Corylus avellana, ELISA, Anisogramma anomala, disease resistance, RAPD marker

\begin{abstract}
Ninety hazelnut (Corylus sp.) genotypes were surveyed for response to the eastern filbert blight pathogen [Anisogramma anomala (Peck) E. Müller] following greenhouse inoculation using a combination of enzyme-linked immunosorbent assay (ELISA) and visual inspection for cankers. Most were cultivars of the European hazelnut (Corylus avellana $\mathrm{L}$.) and a few were interspecific hybrids. Six genotypes did not display signs of the pathogen or symptoms of disease: 'Closca Molla', 'Ratoli', 'Yoder \#5', 'Potomac', 'Medium Long', and 'Grand Traverse'. 'Closca Molla' and 'Ratoli', both minor Spanish cultivars, are superior in many respects to 'Gasaway', which has been extensively used as a completely resistant parent in breeding. 'Potomac' and 'Yoder \#5' have $C$. americana Marsh. in their pedigrees, 'Grand Traverse' is one-quarter $C$. colurna, and the origin of 'Medium Long' is uncertain. The random amplified polymorphic DNA (RAPD) marker generated by primer UBC 152, which is linked to the single dominant resistance gene of 'Gasaway', is absent in these six genotypes, and thus they appear to be novel sources of genetic resistance to this devastating disease.
\end{abstract}

Oregon's Willamette Valley is the top producer of European hazelnuts in the United States, accounting for $99 \%$ of the U.S. crop and $3 \%$ to $5 \%$ of the world crop (Mehlenbacher and Olsen, 1997). Eastern filbert blight (EFB), caused by the pyrenomycete Anisogramma anomala (Peck) E. Müller, is a serious and widespread disease in the Willamette Valley. This disease can destroy the productivity of a moderately susceptible cultivar in 8 to 12 years (Johnson et al., 1996), so its control is an important industry goal. Because of the expense of fungicides and detrimental effects on yield caused by severe pruning of cankers, genetic resistance is an especially appealing approach to fighting this disease (Mehlenbacher, 1995).

\footnotetext{
Received for publication 16 Aug. 1999. Accepted for publication 15 Oct. 1999. Oregon Agricultural Experiment Station Technical Paper No. 11557. This research was supported in part by the Oregon Hazelnut Commission and a specific cooperative agreement with the U.S. Dept. of Agriculture, Agricultural Research Service (USDA, ARS). We thank Kim Hummer, Curator, for access to the collection of the USDA, ARS National Clonal Germplasm Repository for this research. This paper is adapted from a thesis submitted by C.F. Lunde in partial fulfillment of the requirements for a MS degree. The cost of publishing this paper was defrayed in part by the payment of page charges. Under postal regulations, this paper therefore must be hereby marked advertisement solely to indicate this fact.

${ }^{1}$ Former Graduate Research Assistant. Current address: USDA, ARS Plant Gene Expression Center, Albany, CA 94706.

${ }^{2}$ Professor; to whom reprint requests should be addressed. E-mail: mehlenbs@bcc.orst.edu.

${ }^{3}$ Senior Research Assistant.
}

Developing cultivars for the kernel market that are completely resistant to EFB is an important goal of the Oregon State Univ. (OSU) breeding program (Mehlenbacher, 1995). For this market, hazelnuts must meet strict standards for size, shape, shell thickness, ease of pellicle removal, and flavor (Mehlenbacher, 1994). Most of the resistant material in the OSU hazelnut breeding program carries the single, dominant, resistance gene found in the obsolete pollinizer 'Gasaway' (Mehlenbacher et al., 1991). 'Gasaway' has deficiencies in nearly all of these characteristics. Resistant genotypes with good nut quality would be beneficial to the breeding program.

Marker-assisted selection is one tool that breeders can use for early selection; random amplified polymorphic DNA (RAPD) markers are one of the least expensive, rely on the polymerase chain reaction (PCR), and are well suited to the high throughput of breeding programs (Welsh and McClelland, 1990; Williams et al., 1990). Short primers (usually 10 bp) bind to short, inverted repeats that amplify random sequences. These amplified DNA fragments are subjected to electrophoresis and later visualized by ethidium bromide staining. Davis and Mehlenbacher (1997) used bulked segregant analysis (Michelmore et al., 1991) to identify five RAPD markers linked to the 'Gasaway' resistance gene. One of these markers (UBC $152_{800}$ ) is robust to amplification conditions, easy to score, and routinely used to select resistant seedlings in segregating populations (Mehlenbacher and Lunde, unpublished). (Note that primer names are followed by subscripts denoting the size of the polymorphic band that is amplified.)

Concern exists about the durability of the
'Gasaway' source of resistance (Pinkerton et al., 1998). Cultivars differ in level of susceptibility (Pinkerton et al., 1993), but the complete resistance desired by the industry would eliminate the cost of chemical control. Thus, new sources of genes conferring complete resistance would be highly beneficial. The purpose of this study was to survey germplasm from the collections of the OSU breeding program and the U.S. Dept. of Agriculture, Agricultural Research Service (USDA, ARS) National Clonal Germplasm Repository (NCGR), Corvallis, Ore., for response to inoculation by the EFB pathogen.

\section{Materials and Methods}

Plant materials. Three scions of each of 90 hazelnut selections from the NCGR and the collection of the OSU hazelnut breeding program (Table 1) were gathered in Dec. 1996, stored at $0{ }^{\circ} \mathrm{C}$, and grafted onto C. avellana rootstocks in Spring 1997. 'Gasaway' was included as a resistant control and 'Ennis' and 'Daviana' as susceptible controls. Grafted trees were placed in 3.7 - or 5 -L pots in a mix containing equal volumes of peat, pumice, and fine bark dust. In addition, $9 \mathrm{~g}$ of Sierra 3-4 month release fertilizer $(17 \mathrm{~N}-2.6 \mathrm{P}-10 \mathrm{~K}$ with micronutrients) was added to each pot. Supplemental fertilizer (Peters' 20N-8.7P-16.6K) was applied as needed. Plants were grown in a glasshouse under $24^{\circ} \mathrm{C}$ day $/ 18^{\circ} \mathrm{C}$ night until they were ready for inoculation. For genotypes scored as resistant in the first year's inoculations, scions were recollected, grafted, inoculated, and retested in 1998. Genotypes whose grafts failed the first year were also regrafted, inoculated, and assayed in the second year.

Inoculations. Inoculations were started $\approx 3$ to 5 weeks after grafting, once shoots had four to five nodes (Coyne et al., 1996). All actively growing branches (usually two or three) of the grafted trees were marked with tape three or four nodes from the apical meristem to indicate the point of inoculation. Shoots were inoculated with a suspension of $1 \times 10^{6}$ spores/ $\mathrm{mL}$ in distilled water (Johnson et al., 1994). Chamber frames were constructed of polyvinyl chloride tubing (1.27-cm diameter), placed on top of a bench $(1.22 \times 3.44 \mathrm{~m})$ and covered with white 4-mil (0.1-mm) polyethylene sheeting. About 75 trees were placed in each of two inoculation chambers. A humidifier was placed in each chamber, the chamber was closed, and the plastic was fastened with clothespins. The humidifiers were programmed to run from noon to 6 PM and from midnight to 4 AM. The chambers were opened $5 \mathrm{~d}$ after inoculation, left open for $2 \mathrm{~d}$, and then inoculations were repeated. Each tree received a total of three inoculations. They remained in the glasshouse with optimal watering for 6 months prior to assaying for infection.

Infection assays. A combination of three assays was used to detect the presence of $A$. anomala in inoculated shoots. An enzymelinked immunosorbent assay (ELISA) was performed on inoculated shoots of two grafted trees of each genotype as described by Coyne 
et al. (1996), except that Nunc Maxisorp 96well MicroWell Microplates (Fisher Scientific, Pittsburgh) were used instead of Corning microtiter plates. The third grafted tree of each genotype was inoculated as above and transported to the Southwest Washington Experiment Station, Vancouver, Wash.; planted in a nursery row in Feb. 1997; and evaluated for canker incidence in June 1998. Trees that became infected in either of the two assays were scored as susceptible. Genotypes scored as resistant in the first year were retested the second year, using the same inoculation procedures and infection assays, except that tissue was sectioned and examined microscopically for the presence of hyphae in samples that gave inconclusive results with ELISA. Hyphae were stained with $0.05 \%$ trypan blue in lactophenol and observed with a light microscope (Stone et al., 1992).

DNA extraction and RAPD screening. In the spring, DNA was extracted from the very young apical meristem and the first leaf of field-planted trees. When samples were needed later in the season, DNA was extracted from catkins, as Cheng et al. (1997) had successfully extracted DNA from this tissue. The sampled tissues were ground in the laboratory within an hour of field collection. The DNA extraction protocol was based on that of Davis et al. (1998). A leaf juice press (MEKU, Wennigsen, Germany) was used to grind leaf samples with an extraction buffer consisting of $0.35 \mathrm{~m}$ sucrose, $100 \mathrm{~mm}$ Tris, $50 \mathrm{~mm}$ potassium chloride, $25 \mathrm{~mm}$ EDTA, and 5\% PVP (mol. wt. 40,000) dripping onto the grinding bits. About $500 \mu \mathrm{L}$ of the macerate was collected in a $1.7-\mathrm{mL}$ centrifuge tube on ice, and the grinding bits were thoroughly rinsed between samples. Each sample was then centrifuged for $5 \mathrm{~min}$ at $17,900 \mathrm{~g}_{\mathrm{n}}$. The supernatant was discarded and the pellet was resuspended in $640 \mu \mathrm{L}$ lysing buffer [78.3 mм EDTA $\mathrm{pH}$ : 8.0, 39.16 mu Tris- $\mathrm{HCl}$ at $\mathrm{pH} 8.0,2.12 \% \mathrm{n}$ lauroylsarcosine, $2.65 \%$ Triton $\mathrm{X}-100 \AA$, and $10.7 \mu \mathrm{g} \cdot \mu \mathrm{L}^{-1}$ Proteinase-K (Fisher Scientific), which was added just before use]. Samples were incubated for $1 \mathrm{~h}$ at $37^{\circ} \mathrm{C}$ in a shaker at $\approx 160 \mathrm{rpm}$. After centrifugation at $17,900 \mathrm{~g}_{\mathrm{n}}$ for $5 \mathrm{~min}, 500 \mu \mathrm{L}$ of supernatant was transferred to a new tube. An equal volume of cold isopropanol was added, mixed, then tubes were stored in the freezer at $-20^{\circ} \mathrm{C}$ for at least $30 \mathrm{~min}$. Tubes were centrifuged at $17,900 g_{\mathrm{n}}$ for $5 \mathrm{~min}$, the supernatant was discarded, and the remaining liquid was aspirated. The pellet was resuspended in $220 \mu \mathrm{L}$ of $1 \times$ TE buffer $(10 \mathrm{~mm}$ Tris, 1 mm EDTA, pH 8.0) overnight at $4{ }^{\circ} \mathrm{C}$. Samples were extracted with 25 phenol : 24 chloroform : 1 isoamyl alcohol by vortexing $10 \mathrm{~s}$ and then centrifuging for $10 \mathrm{~min}$. A 150$\mu \mathrm{L}$ aliquot of the aqueous phase was transferred to a new tube and precipitated with two volumes of $95 \% \mathrm{EtOH}: 3$ m sodium acetate, pH $5.5(20: 1)$ at $-20^{\circ} \mathrm{C}$ for at least $30 \mathrm{~min}$. The tubes were centrifuged, the supernatant was poured off, and the pellet was washed with $70 \% \mathrm{EtOH}$. The tubes were centrifuged for 5 min, and the supernatant was discarded. The pellet was air-dried overnight and resuspended in $500 \mu \mathrm{L} 1 \times$ TE buffer.
PCR assays. The PCR reactions were performed in a volume of $15 \mu \mathrm{L}$ containing $10 \mathrm{~mm}$ Tris- $\mathrm{HCl}$ (pH 9.0), $50 \mathrm{mM} \mathrm{KCl,} 0.15 \%$ Triton $\mathrm{X}-100,1.5 \mathrm{~mm} \mathrm{MgCl}_{2}, 120 \mu \mathrm{m}$ each of dATP, dCTP, dGTP, and dTTP, $0.1 \mu \mathrm{m}$ of primer, 3 $25 \mathrm{ng}$ of DNA template, and 0.75 units of Taq polymerase (Promega, Madison, Wis.) (Davis and Mehlenbacher, 1997). Ninety-six reactions were run simultaneously using a Geneamp® PCR System 9700 thermal cycler (Perkin-Elmer Corp., Foster City, Calif.). Genotypes that had been scored as resistant, including 'Gasaway', as well as a control containing no DNA, were tested. The thermal cycler program consisted of denaturation for 1 min at $94^{\circ} \mathrm{C}$, followed by 5 cycles of: $1 \mathrm{~min}$ at $94^{\circ} \mathrm{C}, 90 \mathrm{~s}$ at $37^{\circ} \mathrm{C}, 30 \mathrm{~s}$ at $54^{\circ} \mathrm{C}$ and $2 \mathrm{~min}$ at $72^{\circ} \mathrm{C}$. This was followed by 35 cycles of $15 \mathrm{~s}$ at $94{ }^{\circ} \mathrm{C}, 45 \mathrm{~s}$ at $37^{\circ} \mathrm{C}, 30 \mathrm{~s}$ at $54^{\circ} \mathrm{C}$, and $90 \mathrm{~s}$ at $72^{\circ} \mathrm{C}$. Primer extension was for $7 \mathrm{~min}$ at 72 ${ }^{\circ} \mathrm{C}$ and then samples were held at $4{ }^{\circ} \mathrm{C}$ until they were retrieved. The DNA from each tree was amplified using primer UBC 152 (Univ. of British Columbia, Vancouver). Amplification products were separated by electrophoresis on $1.5 \%$ agarose gels, and stained with ethidium bromide. They were visualized with a transilluminator and photographed.

\section{Results and Discussion}

Of the 90 cultivars (Table 1), six, varying widely in agronomic quality, resisted infection by Anisogramma anomala. Desired traits

Table 1. Response of hazelnut cultivars to inoculation with Anisogramma anomala.

\begin{tabular}{|c|c|c|c|c|c|}
\hline Cultivar & Origin & $\begin{array}{l}\text { Accession } \\
(\mathrm{CCOR})^{\mathrm{z}}\end{array}$ & Cultivar & Origin & $\begin{array}{l}\text { Accession } \\
(\mathrm{CCOR})^{\mathrm{z}}\end{array}$ \\
\hline \multicolumn{6}{|c|}{ Noninfected } \\
\hline Closca Molla & Spain & 257 & Potomac & USA-Maryland & 377 \\
\hline Gasaway & USA-Wash. & 54 & Ratoli & Spain & 344 \\
\hline Grand Traverse & USA-Mich. & 559 & Yoder \#5 & USA-Ohio & --- \\
\hline Medium Long & USA-N.Y. & 701 & & & \\
\hline \multicolumn{6}{|c|}{ Infected } \\
\hline A Pellicola Bianca & Italy & 454 & Louisen's Zeller & Germany & 207 \\
\hline Alcover & Italy & 375 & Ludolph's Zeller & Germany & 330 \\
\hline Amandi & Spain & 566 & Martorella & Spain & 444 \\
\hline Apolda & Italy & 360 & Molar & Portugal & 488 \\
\hline Ata Baba & Azerbaijan & 480 & Mogulnuss & England & 324 \\
\hline Atlas & Denmark & 389 & Morell & Spain & 6 \\
\hline Aveline d'Angleterre & England & 387 & Multiflora & England & 322 \\
\hline Bandnuss & England & 382 & Napoletana & Italy & 374 \\
\hline Barcelloner Zeller ${ }^{\mathrm{x}}$ & England & 331 & Napoletanedda & Italy & 463 \\
\hline Bard & England & 514 & Noce Lungha & Italy & 296 \\
\hline Barr's Zeller & England & 333 & Nociara & Italy & 385 \\
\hline Bearn (Du Bearn) & France & 461 & Nottingham & England & 297 \\
\hline Blumberger Zeller ${ }^{\mathrm{x}}$ & Germany & 205 & Palaz & Turkey & 29 \\
\hline Brixley's New & USA-Oregon & 288 & Pallagrossa & Italy & 372 \\
\hline Burchardt's Zeller & Germany & 334 & Pearson's Prolific & England & 335 \\
\hline Buttner's Zeller & Germany & 329 & Pere Mas & Spain & 340 \\
\hline Ceret & Spain & 508 & Pinyolenc & Spain & 339 \\
\hline Cherkesskii II & Russia & 544 & Pioneer & Russia & 548 \\
\hline Comen & Italy & 362 & Planeta & Spain & 445 \\
\hline Comun & Portugal & 486 & Princess Royal & England & 327 \\
\hline Culpla & Spain & 255 & Prolific Closehead & England & 326 \\
\hline da Viega & Portugal & 487 & Purple Aveline & England & --- \\
\hline Daviana $^{\mathrm{w}}$ & England & 42 & Quiros & Spain & 279 \\
\hline Des Anglais & England & 481 & Ratllada & Spain & 442 \\
\hline Ennis $^{\mathrm{w}}$ & USA-Wash. & 11 & Red Filbert & England & 317 \\
\hline Espinaredo & Spain & 509 & Reed & USA-Maryland & 383 \\
\hline Faroka $^{\mathrm{x}}$ & Canada-B.C. & --- & Restiello & Spain & 280 \\
\hline Frizzled Filbert & England & 218 & Riekchen's Zeller & Denmark & 393 \\
\hline Fructo Albo & Italy & 511 & Ros de la Selva & Spain & 260 \\
\hline Garibaldi & England & 338 & Rossetta & Spain & 379 \\
\hline Garrofi & Spain & 341 & Sant Joan ${ }^{\mathrm{x}}$ & Spain & 271 \\
\hline Gironell (Grossal) & Spain & --- & Sant Pere & Spain & 270 \\
\hline Grifoll & Spain & 443 & Sickler's Zeller & Germany & 321 \\
\hline Gunslebener Zeller & Germany & 382 & Sodlinger & Italy & 459 \\
\hline Gustav's Zeller & Germany & 206 & The Shah & England & 319 \\
\hline Heynick’s Zeller & Germany & 390 & Tomasina & Spain & 441 \\
\hline Istarski Duguljasti & Slovenia & 272 & Tonda Bianca & Italy & 21 \\
\hline Jean's & Italy & 264 & Tonda Rossa & Italy & 267 \\
\hline Jeeve's Samling & England & 352 & Truchsess Zeller & Germany & 328 \\
\hline Kadetten Zeller & Germany & 323 & Ugbrooke & New Zealand & 245 \\
\hline Kunzemuller's Zeller & Germany & 353 & Volle Zeller & Germany & --- \\
\hline Lange Landsberger & Germany & 325 & Webb's Prize Cob & England & 336 \\
\hline Liegel's Zeller & Germany & 316 & Witpit Lambertsnoot & Netherlands & 573 \\
\hline
\end{tabular}

${ }^{2}$ Corvallis Corylus (CCOR) accession number assigned by USDA, ARS National Clonal Germplasm Repository, Corvallis, Ore.

${ }^{\mathrm{y}}$ Resistant control.

${ }^{x}$ All grafts failed in 1996; regrafted and tested in 1997. Disease response observed in 1997.

wSusceptible controls. 
for the kernel market are: medium size, round shape, $50 \%$ kernel or better, about two nuts per cluster, very little fiber on the kernel pellicle, good blanching ability, and few defects $(<35 \%)$. Nuts must fall free from the husk because they are mechanically harvested off manicured orchard floors in Oregon. These six cultivars should be useful as parents in the development of new, resistant varieties.

Corylus avellana cultivars. 'Closca Molla' and 'Ratoli', both from Spain, have acceptably round kernels that blanch fairly well. 'Closca Molla' has thin shells (and hence high percentage of kernel) but, unfortunately, low yield, and 'Ratoli' has been recommended as a potential variety in Spain because of its desirable kernel traits (Tasias-Valls, 1975). These cultivars may have potential for immediate use as cultivars in Oregon, but have not yet been included in replicated yield trials.

Interspecific hybrids. At least three of the other four clones are related to species other than C. avellana. 'Grand Traverse' is listed as being the offspring of a cross between 'Faroka' (C. colurna L. X C. avellana) and 'Royal' $(C$. avellana) made by Cecil Farris (Farris, 1989). 'Faroka', selected by J.U. Gellatly in the 1950s from seedlings grown from seed collected from a Turkish tree hazel (C. colurna) growing near European hazels, phenotypically appears to be an interspecific hybrid. Thus, 'Grand Traverse' would be one-quarter $C$. colurna, which partly explains its lack of precocity. Resistance to natural inoculation in this variety was previously reported by Farris (1989). Interestingly, the parent 'Faroka' was infected in our tests, and 'Royal' has been highly susceptible in commercial orchards (Cameron, 1976). The incompatibility alleles of 'Grand Traverse' $\left(S_{11} S_{25}\right)$ indicate that it inherited $S_{11}$ from 'Faroka', but neither allele of 'Royal' $\left(S_{1}\right.$ $S_{3}$ ) is present. This indicates that 'Royal' is not the pollen parent of 'Grand Traverse', and that its EFB resistance may have come from its unknown pollen parent. 'Potomac' is a $C$. americana $\times C$. avellana hybrid, and the appearance of 'Yoder \#5' clearly indicates that it has $C$. americana in its pedigree. Neither of these varieties blanches well. 'Yoder \#5' has the added deficiencies of being low-yielding and quite sensitive to big bud mite (primarily Phytoptus avellanae Nal.). Resistance to EFB has been previously reported in AmericanEuropean hybrids (Coyne et al., 1998) but its genetic control has not been clarified. 'Potomac' is the result of a cross between 'Rush' (a C. americana selection) and 'DuChilly', aEuropean hazelnut cultivar. There are conflicting reports about whether 'Rush' itself is susceptible to EFB (Slate, 1947; Thompson et al., 1996). 'Reed' ['Rush' $x$ 'Bolwyller' (syn. 'Hall's Giant')] has the same
C. americana parent, but was susceptible in the greenhouse inoculation. Other selections from 'Rush' $\times$ C. avellana were resistant in previous tests (Coyne et al., 1998). The parentage of 'Medium Long' is questionable. Some of its ancestors may have included $C$. avellana cultivars imported from Europe, but its resistance to EFB suggests that it may be an interspecific hybrid. We obtained this selection from the New York Agricultural Experiment Station, Geneva, where the European hazel was routinely crossed with $C$. americana and most selections were interspecific hybrids (Slate, 1947).

Release of completely resistant, late-shedding pollenizers is also an objective of the breeding program. These six resistant varieties have diverse self-incompatibility alleles: 'Closca Molla' $\left(\mathrm{S}_{2} \mathrm{~S}_{5}\right)$, 'Ratoli' $\left(\mathrm{S}_{2} \mathrm{~S}_{10}\right)$, 'Grand Traverse' $\left(S_{11} S_{25}\right)$, 'Medium Long' $\left(S_{11} S_{12}\right)$, 'Potomac' $\left(S_{5} S_{12}\right)$, and 'Yoder \# 5' $\left(S_{10} S_{23}\right)$. Incompatibility should not be a barrier to using these cultivars in breeding, and their potential for use as pollenizers deserves attention.

The expected release of varieties carrying the 'Gasaway' gene for resistance to EFB and the nature of the causal fungus indicate that multiple sources of resistance to this disease will be needed for durability. These six cultivars do not amplify the UBC $152_{800}$ marker that is linked to EFB resistance in 'Gasaway' and its progeny, and hence appear to be new sources of genetic resistance. If this is so, the release of new resistant cultivars developed from these six genotypes should provide insurance against new virulence in the pathogen. By deploying varied sources of genetic resistance to EFB, selection pressure for races of Anisogramma anomala able to overcome the 'Gasaway' resistance gene will be lower.

\section{Literature Cited}

Cameron, H.R. 1976. Eastern filbert blight established in the Pacific Northwest. Plant Dis. Rptr. 60:737-740.

Cheng, F.S., S.K. Brown, and N.F. Weeden. 1997. A DNA extraction protocol from various tissues in woody species. HortScience 32:921-922.

Coyne, C.J., S.A. Mehlenbacher, R.O. Hampton, J.N. Pinkerton, and K.B. Johnson. 1996. Use of ELISA to rapidly screen hazelnut for resistance to eastern filbert blight. Plant Dis. 80:13271330.

Coyne, C.J., S.A. Mehlenbacher, and D.C. Smith 1998. Sources of resistance to eastern filbert blight in hazelnut. J. Amer. Soc. Hort. Sci.123:253-257.

Davis, J., D. Henderson, M. Kobayashi, and M.T. Clegg. 1998. Genealogical relationships among cultivated avocado as revealed through RFLP analyses. J. Hered. 89:319-323.

Davis, J.D. and S.A. Mehlenbacher. 1997. Identifi- cation of RAPD markers linked to eastern filbert blight resistance in hazelnut. Acta Hort. 445:553556.

Farris, C.W. 1989. Two new introductions: 'Grand Traverse' hazelnut and 'Spartan' seedless grape. Annu. Rpt. Northern Nut Growers Assoc. 80:102-103.

Johnson, K.B., S.A. Mehlenbacher, J.K. Stone, J.W. Pscheidt, and J.N. Pinkerton. 1996. Eastern filbert blight of European hazelnut: It's becoming a manageable disease. Plant Dis. 80:1308-1316.

Johnson, K.B., J.N. Pinkerton, S.M. Gaudreault, and J.K. Stone. 1994. Infection of European hazelnut by Anisogramma anomala: Site of infection and effect of host developmental stage. Phytopathology 84:1465-1470.

Mehlenbacher, S.A. 1991. Hazelnuts (Corylus). Genetic resources of temperate fruit and nut crops. Acta Hort. 290:791-836.

Mehlenbacher, S.A. 1994. Genetic improvement of the hazelnut. Acta Hort. 351:23-38.

Mehlenbacher, S.A. 1995. Progress in breeding new hazelnut cultivars in Oregon. Nucis Nwsl. 3:8-9.

Mehlenbacher, S.A. and J. Olsen. 1997. The hazelnut industry in Oregon, USA. Acta Hort. 445:337-345

Mehlenbacher, S.A., M.M. Thompson, and H.R. Cameron. 1991. Occurrence and inheritance of resistance to eastern filbert blight in 'Gasaway' hazelnut. HortScience 26:410-411.

Michelmore, R.W., I. Paran, and R.V. Kesseli. 1991. Identification of markers linked to disease-resistance genes by bulked segregant analysis: A rapid method to detect markers in specific genomic regions by using segregating populations. Proc. Natl. Acad. Sci. U.S.A. 88:98299832.

Pinkerton, J.N., K.B. Johnson, S.A. Mehlenbacher, and J.W. Pscheidt. 1993. Susceptibility of European hazelnut clones to eastern filbert blight. Plant Dis. 77:261-266.

Pinkerton, J.N., K.B. Johnson, J.K. Stone, and K.L. Ivors. 1998. Maturation and seasonal discharge pattern of ascospores of Anisogramma anomala. Phytopathology 88:1165-1173.

Slate, G.L. 1947. Some results with filbert breeding at Geneva, NY. Annu. Rpt. Northern Nut Growers Assoc. 38:94-100.

Stone, J.K., K.B. Johnson, J.N. Pinkerton, and J.W. Pscheidt. 1992. Natural infection period and susceptibility of vegetative seedlings of European hazelnut to Anisogramma anomala. Plant Dis. 76:348-352.

Tasias-Valls, J. 1975. El avellano en la provincia de Tarragona. Excma. Diputación Provincial de Tarragona. Fundación Servicio Agropecuario Provincial.

Thompson, M.M., H.B. Lagerstedt, and S.A. Mehlenbacher. 1996. Hazelnuts, p. 125-184. In: J. Janick and J.N. Moore (eds.). Fruit breeding, Vol. III: Nuts. Wiley, New York.

Welsh, J. and M. McClelland. 1990. Fingerprinting genomes using PCR with arbitrary primers. Nucleic Acids Res. 18:7213-7218.

Williams, J.G.K., A.R. Kubelik, K.J.Livak, J. Antoni Rafalski, and S.V. Tingey. 1990. DNA polymorphisms amplified by arbitrary primers are useful as genetic markers. Nucleic Acids Res. 18:6531-6535. 